\title{
Oil removal from oil/water emulsion by Zeolitic Imidazolate Framework-8 (ZIF-8): A study of pH, and adsorption kinetic
}

Remoção de óleo da emulsão de óleo/água por Zeolitic Imidlazolate Framework-8 (ZIF8): Um estudo de pH e cinética de adsorção

Eliminación de aceite de la emulsión de aceite/agua mediante Zeolitic Imidazolate Framework-8 (ZIF-8): un estudio de pH y cinética de adsorción

Thianne Silva Batista Barbosa ORCID: https://orcid.org/0000-0002-1828-8546 Universidade Federal de Campina Grande, Brasil E-mail: thianne.siilva@gmail.com

Thiago Rodrigo Barbosa Barros ORCID: https://orcid.org/0000-0002-0857-2017 Universidade Federal de Campina Grande, Brasil

E-mail: thiagojdbarbosa@gmail.com

Tellys Lins Almeida Barbosa ORCID: https://orcid.org/0000-0002-3733-4333 Universidade Federal de Campina Grande, Brasil

E-mail: tellyslins@hotmail.com

Diogo Pierre Alves Rodrigues ORCID: https://orcid.org/0000-0002-7327-1886 Universidade Federal de Campina Grande, Brasil E-mail: diogopierrealvesrodrigues@gmail.com

Meiry Gláucia Freire Rodrigues ORCID: https://orcid.org/0000-0003-2258-4230 Universidade Federal de Campina Grande, Brasil E-mail: meiry.rodrigues@ufcg.edu.br

\begin{abstract}
Most traditional methods are only used to remove free oil from wastewater, and they are not efficient for separating oilwater emulsions. The adsorption separation process can be widely applied for the treatment of emulsions, mainly due to the cost and benefit of the process and the wide variety of materials that can be used as adsorbents, for example activated carbon, clays, zeolites, etc. Among the various types of porous materials called "Metal Organic Frameworks" (MOFs) are the zeolitic imidazolate (ZIFs) structures. The zeolitic structure of the ZIFs allows to exhibit high surface areas and thus to be promising adsorbents. To evaluate the adsorption capacity of ZIF-8 in the removal of emulsified oil, ZIF-8 was synthesized using Zn metal and as organic binder 2-methylimidazole (Hmim), dissolved in methanol at room temperature. ZIF-8 was characterized by X-ray diffraction (XRD) technique to determine the crystalline structure. To evaluate the capacity of the emulsified oil, a $\mathrm{pH}$-influence test and chemical kinetics were determined. The best $\mathrm{pH}$ of the emulsion for removal was $\mathrm{pH} 6$. The chemical kinetics performed at $\mathrm{pH} 6$ presented the best fit with the pseudosecond model with correlation coefficient 0.93 . According to the kinetic data, a removal percentage of $92.43 \%$ was found with only $30 \mathrm{~min}$ of removal.
\end{abstract}

Keywords: Zeolitic imidazolate frameworks; Nanocrystals; Emulsion oil/water; Adsorption; Kinetics.

\section{Resumo}

A maioria dos métodos tradicionais são usados apenas para remover óleo livre de águas residuais e não são eficientes para separar emulsões de óleo-água. O processo de separação por adsorção pode ser amplamente aplicado para o tratamento de emulsões, principalmente pelo custo e benefício do processo e pela grande variedade de materiais que podem ser utilizados como adsorventes, por exemplo, carvão ativado, argilas, zeólitas, etc. vários tipos de materiais porosos chamados "Estruturas Metálorgânicas" (MOFs) são as estruturas de imidazolato zeolítico (ZIFs). A estrutura zeolítica dos ZIFs permite exibir altas áreas superficiais específicas e, portanto, ser adsorventes promissores. Para avaliar a capacidade de adsorção do ZIF-8 na remoção do óleo emulsionado, o ZIF-8 foi sintetizado utilizando o Zn metálico e como ligante orgânico 2-metilimidazol (Hmim), dissolvido em metanol à temperatura ambiente. O ZIF-8 foi caracterizado pela técnica de difração de raios X (XRD) para determinar a estrutura cristalina. Para avaliar a capacidade do óleo emulsionado, um teste de influência do $\mathrm{pH}$ e cinética química foram determinados. O melhor pH da emulsão 
para remoção foi $\mathrm{pH}$ 6. A cinética química realizada em pH 6 apresentou o melhor ajuste com o modelo de pseudosegundo com coeficiente de correlação de 0,93 . De acordo com os dados cinéticos, um percentual de remoção de $92,43 \%$ foi encontrado com apenas 30 minutos de remoção.

Palavras-chave: Zeolitic imidazolate frameworks; Nanocristais; Emulsão óleo/água; Adsorção; Cinética.

\section{Resumen}

La mayoría de los métodos tradicionales solo se utilizan para eliminar el aceite libre de las aguas residuales y no son eficaces para separar las emulsiones de aceite y agua. El proceso de separación por adsorción se puede aplicar ampliamente para el tratamiento de emulsiones, principalmente por el costo y beneficio del proceso y la amplia variedad de materiales que pueden usarse como adsorbentes, por ejemplo carbón activado, arcillas, zeolitas, etc. Entre los varios tipos de materiales porosos denominados "estructuras orgánicas metálicas" (MOF) son las estructuras de imidazolato zeolítico (ZIF). La estructura zeolítica de los ZIF permite exhibir áreas superficiales elevadas y, por lo tanto, ser adsorbentes prometedores. Para evaluar la capacidad de adsorción de ZIF-8 en la eliminación de aceite emulsionado, se sintetizó ZIF-8 utilizando Zn metálico y como aglutinante orgánico 2-metilimidazol (Hmim), disuelto en metanol a temperatura ambiente. ZIF-8 se caracterizó mediante la técnica de difracción de rayos X (XRD) para determinar la estructura cristalina. Para evaluar la capacidad del aceite emulsionado, se determinó una prueba de influencia del $\mathrm{pH}$ y la cinética química. El mejor pH de la emulsión para remoción fue pH 6. La cinética química realizada a pH 6 presentó el mejor ajuste con el modelo de pseudo-segundo con coeficiente de correlación 0.93. Según los datos cinéticos, se encontró un porcentaje de remoción del $92.43 \%$ con solo 30 min de remoción.

Palabras clave: Estructuras de imidazolato zeolítico; Nanocristales; Emulsión de aceite/agua; Adsorción; Cinética.

\section{Introduction}

As oily wastewater, they are also identified as oily effluents, are a class of generalized pollutants from various types of sources that have a major impact on the environment (Tian et al., 2019). In addition to being toxic, oily wastewater contains petroleum hydrocarbons, phenols and poly aromatic hydrocarbons that can slow the growth of animals and plants. As for humans, this pollutant generates risks of mutations and cancers (Ismail et al., 2020).

Oils in wastewater can be found in different forms free, emulsified and dispersed (Pintor et al., 2016). The emulsified oil has particles smaller than $20 \mu \mathrm{m}$ in diameter and the drops are stabilized by the chemical action of surface agents (Pintor et al., 2016). Emulsions are more difficult to treat due to their high stability in the aqueous phase (Wahi et al., 2013).

Emulsion is a colloidal system in which one phase (oil or water) is uniformly dispersed in another phase (water or oil) (Zhan et al., 2019; Li et al., 2020). Depending on the relative volumetric ratio between the two phases, emulsions can be simple water-in-oil $(\mathrm{W} / \mathrm{O})$ or oil-in-water $(\mathrm{O} / \mathrm{W})$.

Various separation techniques emulsion O/W (also called demulsification) have been proposed, such as membrane separation, chemical destabilization, electrocoagulation, floating and adsorption (Arthur et al., 2005; Obaid et al., 2015; Drioli and Romano, 2001; Zhu et al., 2014).

Given the cost and convenience of the operation, adsorption is one of the most common techniques for demulsification (Lin, Chen, \& Phattarapattama, 2016) and removal of organic pollutants (Awad, et al., 2019). The use of the adsorption process as a contaminant removal technology stands out especially due to the high variety of adsorbent materials that can be applied. Each adsorbent has its own characteristics, such as porosity, pore structure and nature of its adsorption surfaces (Rashed, 2013).

Since 1995, a new class of porous materials called "Metal Organic Frameworks (MOFs)" has been developed and increasingly explored in various fields (Lin, Chen, \& Phattarapattama, 2016). Among these various types of MOFs, zeolitic imidazolate (ZIFs) structures represent a unique subset of MOFs that are topologically like zeolites. ZIFs are composed of tetrahedrally coordinated transition metal ions ( $\mathrm{Fe}, \mathrm{Co}, \mathrm{Cu}, \mathrm{Zn}$ ) connected by organic imidazole linkers (Melgar, Kim, \& Othman, 2015).

The zeolitic structure of the ZIFs allows to display elevated surface areas and thus to be promising adsorbents (Phan et al., 2010). These materials become increasingly attractive due to the mild synthesis conditions compared to the synthesis of zeolites, which are required at high temperatures (Payra et al., 2019). 
Our research group has published some papers on the production of adsorbents and zeolite membranes for separation oil/water and ZIF-8 (Rodrigues, Barbosa, \& Rodrigues, 2020; Rodrigues, Rodrigues \& Barbosa, 2019; Rodrigues et al., 2019; Barbosa, Barbosa, \& Rodrigues, 2015; Scheibler et al., 2014; Barbosa et al., 2020; Barbosa, Barbosa, \& Rodrigues, 2015). In addition, a series of studies were developed in the preparation of ZIFs and various applications (Barbosa, 2019; Tomaz, 2020; Rodrigues, Barbosa, \& Rodrigues, 2020; Rodrigues, Barbosa, \& Rodrigues, 2020; Tomaz et al, 2021; Rodrigues, 2021).

Among the ZIF family, ZIF-8 is constructed with tetrahedral bridged $\mathrm{Zn}^{2}{ }^{+}$with 2 -methyl imidazole units (Chen et al., 2014). According to authors (Sann et al., 2018) ZIF-8 exhibits strong hydrophobicity and great super oleophilic properties, which offers the possibility of rapidly removing organic oils or solvents from the water surface. As well as having exceptional chemical and thermal stability that favors the recycling and reuse in the separation of oil in water. Thus, the objective of this work was to synthesize ZIF-8 to evaluate its adsorption capacity of emulsified oil.

\section{Methodology}

This work was carried out at the Laboratório de Desenvolvimento de Novos Materiais (LABNOV), belonging to the Unidade Acadêmica de Engenharia Química, located at the Centro de Ciências e Tecnologia of the Universidade Federal de Campina Grande (UAEQ/CCT/UFCG).

\subsection{Materials}

All chemicals and solvents were purchased from commercial suppliers and used as received (without further purification) included zinc nitrate hexahydrate $\left(\mathrm{Zn}\left(\mathrm{NO}_{3}\right)_{2} \cdot 6 \mathrm{H}_{2} \mathrm{O}\right.$, Acros Organics, $\left.98 \%\right)$, 2-methylimidazole $\left(\mathrm{CH}_{3} \mathrm{C}_{3} \mathrm{H}_{2} \mathrm{~N}_{2} \mathrm{H}\right.$, Aldrich, 99\%), methanol P.A. $\left(\mathrm{CH}_{3} \mathrm{OH}\right.$, Neon, $\left.99.9 \%\right)$, chloroform P.A. $\left(\mathrm{CHCl}_{3}\right.$, Dinâmica, $\left.99.9 \%\right)$, deionized water. Lubricant oil (LUBRAX, SL SAE 20W/50 API SL) was supplied by Petrobras. Distilled water and chloroform were also purchased $\left(\mathrm{CHCl}_{3}\right.$, Dinâmica, $\left.99.8 \%\right)$.

\subsection{Synthesis of ZIF-8 nanocrystals}

A synthesis protocol reported by authors (Cravillon et al. 2009; Rodrigues, Barbosa, \& Rodrigues, 2020) was taken as reference. Solution (A): zinc nitrate hexahydrate $(1.47 \mathrm{~g}, 4.94 \mathrm{mmol})$ was dissolved in methanol (100 mL) and remained under stirring for 30 minutes with a magnetic bar. Solution (B): 2-methylimidazole (3.25 g, $39.58 \mathrm{mmol})$ was dissolved in methanol $(100 \mathrm{~mL})$ and remained under stirring for 30 minutes with a magnetic bar. The latter clear solution (B) was poured into the former clear solution (A). Then, blended and stirred magnetically at room temperature $25^{\circ} \mathrm{C}$ for $1 \mathrm{~h}$. The mixture quickly turned turbid (milky colloidal dispersion) with a molar composition of $\mathrm{Zn}^{2+}$ : 2-methylimidazole: methanol $=1: 8: 1001$. The resulting ZIF-8 nanocrystals were collected by centrifugation (3400 rpm/15 minutes) using a Cole-Parmer fixed-speed centrifuge. Supernatant was removed and stored. The precipitate was thoroughly washed with fresh methanol $(\sim 1 \mathrm{~mL})$ and centrifugated (3400 rpm/15 minutes) for three times. The nanocrystals were dried in an oven (Quimis) at $60^{\circ} \mathrm{C}$ for $24 \mathrm{~h}$ to yield white-colored ZIF-8. Fig. 1 shows a schematic of ZIF-8 nanocrystals synthesis. 
Figure 1. Schematic representation of ZIF-8 nanocrystals nanocrystals synthesis.

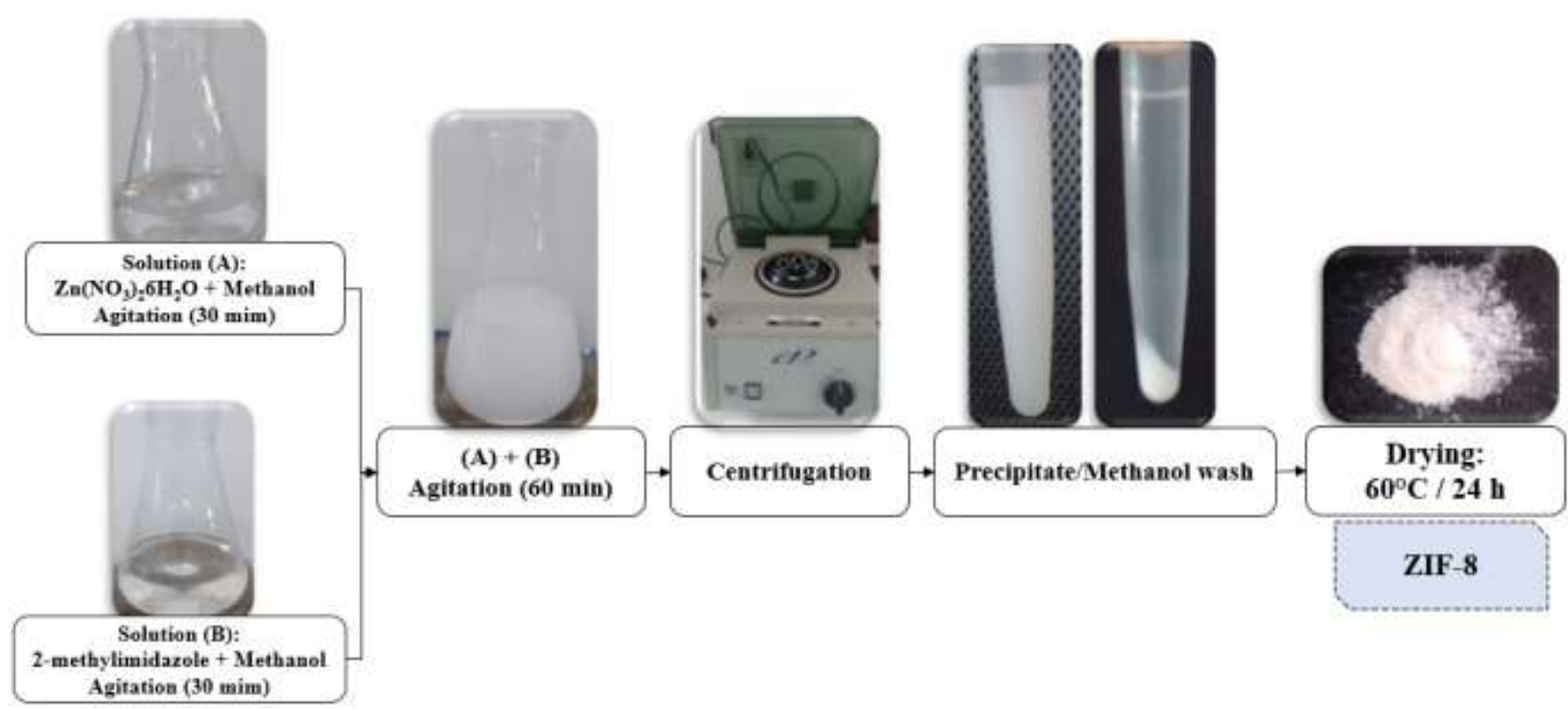

Source: Authors.

\subsection{Characterization}

\subsubsection{X-ray diffraction $(X R D)$}

Powder X-ray diffraction (XRD) patterns were obtained with an X-ray diffractometer Shimadzu (XRD 6000, Kyoto, Japan) using $\mathrm{Cu} \mathrm{K \alpha}$ radiation at $40 \mathrm{kV} / 30 \mathrm{~mA}$, with goniometer velocity of $2 \% \mathrm{~min}$ and step of $0.02^{\circ}$ in the $2 \theta$ range from $3.0^{\circ}$ to $50.0^{\circ}$.

\subsubsection{Density and Viscosity}

The density of the sample was determined at $29.5^{\circ} \mathrm{C}$ with a digital Anton Paar densitometer, model 30px. A 2-mL aliquot of lubricating oil was added to the densimeter, and the result was recorded. Viscosity measurements were carried out with lubricating oil by using the Brookfield DV-II Pro(rotational) viscometer.

\subsection{Emulsion oil/water separation}

The emulsion $\mathrm{O} / \mathrm{W}$ was prepared using mineral-based automotive lubricating oil, sold commercially by the company Petrobras. The properties of lubricant oil are given in Table 1.

Table 1. Properties of lubricant oil selected for this present study.

\begin{tabular}{ccc}
\hline Characteristics & Method & Specification \\
\hline Appearance at $30^{\circ} \mathrm{C}$ & Visual & Clear liquid \\
Density at $29.5^{\circ} \mathrm{C}, \mathrm{g} \mathrm{m}^{-1}$ & IS 1115-86 P: 32 & 0.8833 \\
Kinematic viscosity at $40^{\circ} \mathrm{C}, \mathrm{cSt}$ & IS 1115-86 P: 25 & 168 \\
\hline
\end{tabular}

Source: Tomaz (2020).

The performance of ZIF-8 in oil-water separation was evaluated using oil/water emulsion made of lubricant oil and distilled water. Oil/water emulsions were prepared using lubricant oil $(\sim 0.005 \mathrm{~g})$ and were emulsified in 
distilled water $(0.05 \mathrm{~L}$ ) under 17,000 rpm on a mechanical disperser (Marconi, MA 147) for $20 \mathrm{~min}$. The oil/water emulsions were cooled at room temperature and the concentration of each emulsion oil $\left(\mathrm{C}_{0}, \mathrm{mg} / \mathrm{L}\right)$ was analyzed by $\mathrm{UV}$-visible spectroscopy by the chloroform method.

The chloroform method (Mota, Rodrigues, \& Machado, 2014) will be applied to determine the oil concentrations of the samples. For this purpose, chloroform is used as an oil extractor present in the emulsion in a 1: $1(\mathrm{v} / \mathrm{v})$ ratio. The mixture (chloroform and oil/water emulsion) mixed on a shaking table (Braun Certomat MO, Biotech International, Germany) at 200 $\mathrm{rpm}$ for $5 \mathrm{~min}$ at $25^{\circ} \mathrm{C}$ room temperature. After agitation, the denser phase was analysed by UV-VIS 1600 (Pro-Analysis) absorption spectrophotometer in the region of ultraviolet-visible at $262 \mathrm{~nm}$ wavelength.

A calibration curve of absorbance versus oil concentration was constructed (absorbance versus concentration). Oil was dissolved in distilled water and standard solutions were obtained with different initial concentrations $(0-100 \mathrm{mg} / \mathrm{L})$. The curve was plotted and the absorbance coefficient according to the Lambert-Beer Law was calculated using a linear fit. From the curve, it was possible to determine oil concentration.

Total removal percentage of oil (\% Rem) and adsorption capacity of heavy metal at equilibrium $\left(\mathrm{q}_{\mathrm{eq}}\right)$ were calculated based on Equations (1) and (2), respectively:

$$
\begin{aligned}
& \% \operatorname{Rem}=\left(\frac{\mathrm{C}_{\mathrm{i}}-\mathrm{C}_{\mathrm{f}}}{\boldsymbol{C}_{\boldsymbol{i}}}\right) \times 100 \\
& \mathrm{q}_{\text {eq }}=\frac{\mathrm{V}_{\text {emulsion }} \times\left(\mathrm{C}_{\mathrm{i}}-\mathrm{C}_{\mathrm{f}}\right)}{\mathrm{m}_{\text {ZIF- } 8}}
\end{aligned}
$$

Where $C_{i}(m g / L)$ is the initial oil concentration; $C_{f}(m g / L)$ is the final oil concentration after removal; $V_{\text {emulsion }}(\mathrm{L})$ is the total volume of oil/water emulsion used during the batch process system and $\mathrm{m}_{\mathrm{ZIF}-8}(\mathrm{~g})$ denotes the mass of ZIF-8 used for demulsification.

\subsection{Influence of $\mathrm{pH}$}

Emulsion $\mathrm{pH}$ is a parameter of significant relevance in determining adsorption capacity (Lin, Chen, \& Phattarapattama, 2016). The adsorption of emulsion oil/water over varying $\mathrm{pH}$ (from 2.0 to 14.0) was studied under the following experimental conditions: emulsion oil/water with an initial concentration $(500 \mathrm{mg} / \mathrm{L})$; ZIF-8 powder $(0.020 \mathrm{~g}) ; 200 \mathrm{rpm}$ stirring at $25^{\circ} \mathrm{C}$ and $120 \mathrm{~min}$. The samples were acidified and alkalized with 3M hydrochloric acid and $1 \mathrm{M}$ sodium hydroxide solutions, respectively.

\subsection{Adsorption kinetics}

Based on reports from the reviewed literature, the ideal temperature for adsorption of oil is room temperature (Rodrigues et al., 2010). Most authors reported a time of 1-6 h for adsorption process in the laboratory (Rodrigues et al., 2010, Mota, Rodrigues, \& Machado, 2014).

Emulsion oil/water adsorption kinetics was acquired in batch experiments with constant stirring (Tien, 1994). These experiments were performed at room temperature using a solution of $500 \mathrm{mg} / \mathrm{L}$ of oil/water emulsion, which was put in contact with $0.050 \mathrm{~g}$ of ZIF-8. Adsorption experiments were conducted in conical flasks at controlled $\mathrm{pH}$ and under mechanical stirring at $200 \mathrm{rpm}$ (Certomat MO). Aliquots from the solution were collected at different time intervals between 0 and $120 \mathrm{~min}$. Afterward, the solutions were centrifuged and analyzed for residual oil/water emulsion concentration with a UV-VIS 1600 (ProAnalysis) absorption spectrophotometer in the region of ultraviolet-visible 
According to authors (Ho \& Mckay, 1999; Ho \& Mckay, 1999), several kinetic models have been used to examine the adsorption mechanism. To investigate the mechanism of adsorption kinetics, we will use the pseudo-first order and pseudosecond-order model developed by authors (Ho \& Mckay, 1998; Ho \& Mckay, 1999). The pseudo-first order model is represented by the equation 3 and, the model of the pseudo-second order according to authors (Ho \& Mckay, 1999) is shown as equation 4.

$$
\begin{aligned}
& \mathbf{q}_{t}=q_{e}\left(1-e^{-k_{1} t}\right) \\
& q_{t}=\frac{K \cdot q_{e q}^{2} \cdot t}{\left(1+t \cdot K_{2} \cdot q_{e}\right)}
\end{aligned}
$$

Where, $\mathrm{K}_{1}=$ Constant of pseudo first order (g/mg.h), $\mathrm{q}_{\mathrm{t}}$ and $\mathrm{q}_{\mathrm{e}}=$ time and equilibrium adsorbed amounts (mg/g), respectively, $\mathrm{K}_{2}=$ Constant of pseudo second order (g/mg.h).

\section{Results and Discussion}

\subsection{Characterization: X-ray diffraction (XRD)}

Figure 2 shows pattern powder as a synthesized ZIF-8 nanocrystals and the simulated pattern from the published ZIF- 8 structure data (Park et al., 2006).

Figure 2. XRD pattern of ZIF-8 nanocrystals synthesized (black pattern) and XRD pattern simulated from ZIF-8 crystal

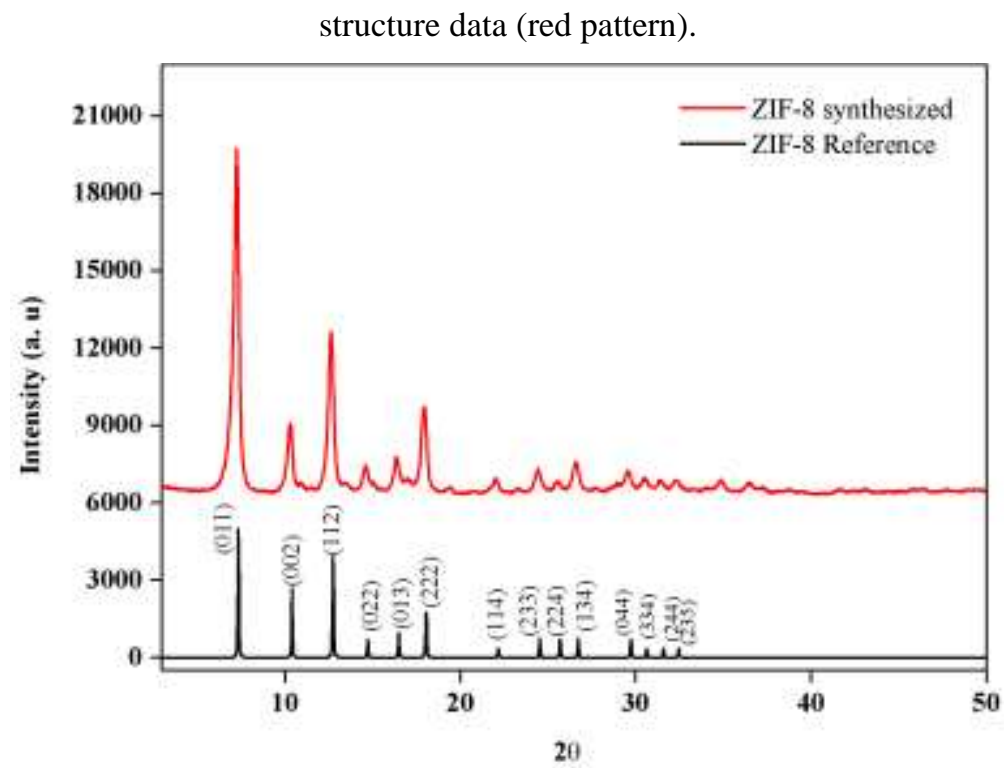

Source: Authors.

According to the diffractogram in Figure 2, it is possible to evidence the presence of the high intensity peak at $2 \theta=$ $7.21^{\circ}$, corresponding to the main reflection plane 011 , with respect to the crystal structure of ZIF-8. Other average peaks at $2 \theta$ $=10.25^{\circ}, 14.50^{\circ}$ and $16.31^{\circ}$ attributed to the low intensity planes (002), (022), (013), respectively, were also identified. It was observed that the diffraction patterns of the metalorganic structure of ZIF-8 agree with the reference patterns from the data of the ZIF-8 structure published (Park et al., 2006), this shows that the synthesized material is highly crystalline and without 
impurities. The ZIF-8 diffraction patterns are in accordance with the literature (Sann et al., 2018; Cravillon et al., 2009; Pan et al., 2011; Rodrigues; Barbosa; Rodrigues, 2020), indicating that the structure was efficiently synthesized.

\subsection{Influence of pH}

The $\mathrm{pH}$ value of the aqueous solution plays an important role in the emulsion oil/water adsorption. Hence, the effect of $\mathrm{pH}$ on the emulsion oil/water adsorption by ZIF-8 nanocrystals was studied, and the results are presented in Figure 3.

Figure 3. Effects of $\mathrm{pH}$ on the removal of emulsion oil/water by ZIF-8 nanocrystals.

Experimental conditions: $\mathrm{C}_{0}$ (emulsion oil/water) $=500 \mathrm{mg} / \mathrm{L}$ in $50 \mathrm{ml}$ emulsion oil $/$ water at $25^{\circ} \mathrm{C}, 200 \mathrm{rpm}$.

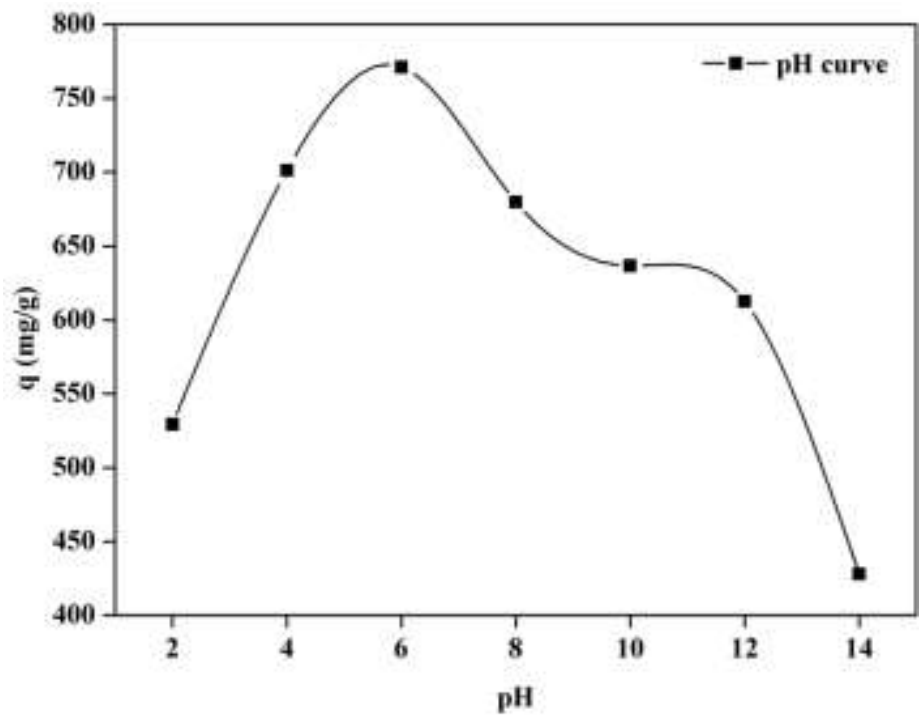

Source: Authors.

According to Figure 3 it is found that the emulsion $\mathrm{pH} 6$ is the most favorable for the adsorption process. It is also found that very acidic emulsion at $\mathrm{pH} 2$ and very basic emulsion at $\mathrm{pH} 14$ does not favor adsorption. To study the influence of the $\mathrm{pH}$ on the adsorption capacity of materials, experiments were performed varying the $\mathrm{pH}$ from 2 to 14 . Table 2 shows total removal percentage of oil (\% Rem) and adsorption capacity (q) for each $\mathrm{pH}$ of the emulsion analyzed.

Table 2. Effects of $\mathrm{pH}$ on the removal of emulsion oil/water by ZIF-8.

\begin{tabular}{ccc}
\hline $\mathbf{p H}$ & \% Removal & $\mathbf{q}(\mathbf{m g} / \mathbf{g})$ \\
\hline $\mathbf{2}$ & 67.24 & 529.50 \\
$\mathbf{4}$ & 89.04 & 701.25 \\
$\mathbf{6}$ & 97.93 & 771.20 \\
$\mathbf{8}$ & 86.33 & 679.87 \\
$\mathbf{1 0}$ & 80.84 & 636.65 \\
$\mathbf{1 2}$ & 77.79 & 612.60 \\
$\mathbf{1 4}$ & 54.36 & 428.12 \\
\hline
\end{tabular}

Source: Authors.

The values of percentage removal and adsorption capacity shown in the Table show that ZIF-8 adsorption capacity under extreme acidity and basicity conditions are negatively affected. However, under slightly acidic conditions the adsorption 
capacity is higher than under alkaline conditions. The $\mathrm{pH}$ is a critical parameter that directly influences emulsion stability. The authors (Lin et al., 2016; Shams et al., 2016) also states that the adsorption capacity of ZIF-8 is quite stable under neutral and acid emulsion conditions, due to the strong electrostatic attraction and hydrophobic interaction existing between the ZIF-8 positive particles and the emulsion negative particles.

\subsection{Adsorption kinetics}

The emulsion $\mathrm{O} / \mathrm{W}$ used for the adsorption kinetics was adjusted in $\mathrm{pH}$ 6. The values of total removal percentage of oil (\% Rem) and adsorption capacity (q) for each stirring time obtained in the tests for studies of adsorption kinetics are shown in Table 3.

Table 3. Adsorption kinetics data.

\begin{tabular}{ccc}
\hline Time (min) & \% Removal & $\mathbf{q}(\mathbf{m g} / \mathbf{g})$ \\
\hline $\mathbf{1 0}$ & 79.36 & 1043.62 \\
$\mathbf{2 0}$ & 84.09 & 1105.77 \\
$\mathbf{3 0}$ & 92.44 & 1215.55 \\
$\mathbf{4 0}$ & 95.03 & 1249.70 \\
$\mathbf{5 0}$ & 95.95 & 1261.70 \\
$\mathbf{6 0}$ & 97.37 & 1280.37 \\
$\mathbf{7 0}$ & 96.76 & 1272.40 \\
$\mathbf{8 0}$ & 97.80 & 1286.02 \\
$\mathbf{9 0}$ & 99.43 & 1307.45 \\
$\mathbf{1 0 0}$ & 99.17 & 1304.07 \\
$\mathbf{1 1 0}$ & 99.06 & 1302.65 \\
$\mathbf{1 2 0}$ & 97.00 & 1275.57 \\
\hline
\end{tabular}

Source: Authors.

The values of total removal percentage of oil shown in Table 3 is highly satisfactory as it shows rapid adsorption kinetics, from 30 minutes the equilibrium of the adsorption of the oil present in the emulsion with ZIF-8 was achieved. It is also possible to verify high values for the adsorption capacity above $1000 \mathrm{mg} / \mathrm{g}$ in the first 10 minutes. However, stands out the 90 min with $99.43 \%$ removal and $1307.45 \mathrm{mg}$ of oil/gram of ZIF-8.

Figure 4 show the kinetic curves obtained from the emulsion oil/water adsorption tests for ZIF-8, fit to the pseudo-first order model (Ezzati, 2020) and pseudo-second order model (Bullen et al., 2021). 
Figure 4. Adsorption kinetics adjusted to the pseudo-first and pseudo-second order model.

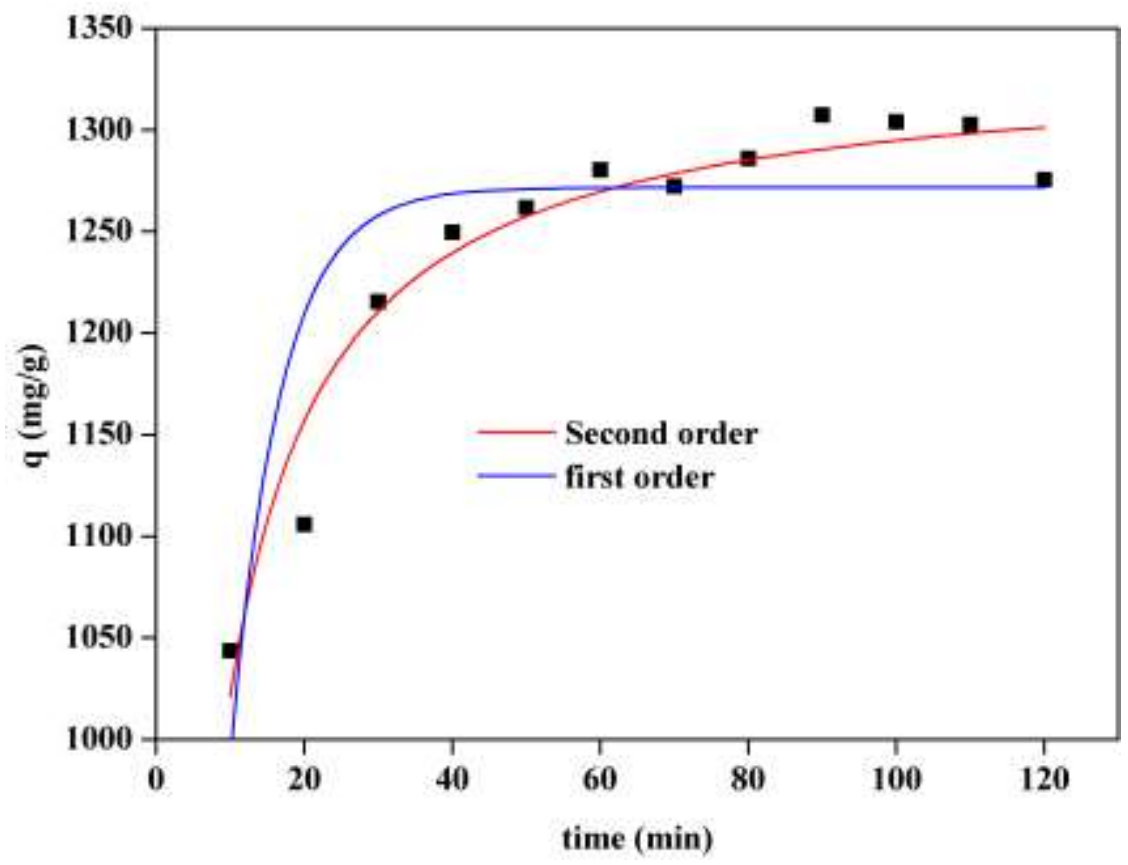

Source: Authors.

Table 4 shows the kinetic parameters of the pseudo first and pseudo-second order models that were obtained from the non-linear model generated by the Origin $8.0 ®$ software. The pseudo first order model did not fit favorably the adsorption kinetics as it presented a low correlation coefficient $\mathrm{R}^{2}$ of 0.720 .

Table 4. Pseudo-second-order model constants and correlation coefficients for oil/water emulsion adsorption onto ZIF-8.

\begin{tabular}{cccc}
\hline Model & $\mathbf{R}^{\mathbf{2}}$ & $\mathbf{q e}(\mathbf{m g} / \mathbf{g})$ & $\mathbf{K}$ \\
\hline Pseudo second order & 0.933 & 1334.58 & $2.44 \mathrm{E}^{-4}$ \\
Pseudo first order & 0.720 & 1271.62 & 0.151 \\
\hline
\end{tabular}

Source: Authors.

The adsorption process that follows this model is characterized by chemoreaction, as described by authors (Ho \& McKay, 1999), which points to the chemical nature of adsorbent-adsorbent interactions. In this type of adsorption, molecules are not attracted to all points of the solid's surface, but specifically to the active centers, to form a single layer initially. In chemisorption, oil droplets can adhere to the surface of ZIF-8 forming a covalent chemical bond.

\section{Conclusion}

In conclusion, the crystalline phase of ZIF-8 nanocrystals was successfully obtained by the solvothermal method.

The effects of process parameters such as $\mathrm{pH}$ and initial concentration were studied. The solution $\mathrm{pH}$ plays a significant role in influencing the capacity of an adsorbent towards emulsified oil.

The ZIF-8 nanocrystals presented a high affinity to the emulsified oil. A pseudo-second-order kinetic model represented well the mechanism of interaction involved during emulsified adsorption of the ZIF-8.

The present investigation shows that ZIF-8 nanocrystals is an effective nanoadsorbent for the adsorption of oil. 
The present study represents the development of suitable strategies to prepare nanomaterials for current application in the removal of oil, as well as future applications in the release of drugs and nanotechnology.

\section{Acknowledgments}

The authors gratefully acknowledge the CNPq (Conselho Nacional de Desenvolvimento Científico e Tecnológico) and the CAPES (Coordenação de Aperfeiçoamento de Pessoal de Nível Superior) for the financial support.

\section{References}

Arthur, J. D., Langhus, B. G., \& Patel, C., (2005). Technical summary of oil \& gas produced water treatment technologies. All Consulting, LLC, Tulsa.

Awad, A. M., Shaikh, S. M. R., Jalab, R., Gulied, M. H., Nasser, M. S., Benamor, A., \& Adham, S. (2019). Adsorption of organic pollutants by natural and modified clays: A comprehensive review. Separation and Purification Technology, 228, 115719. https://doi.org/10.1016/j.seppur.2019.115719

Barbosa, A. S., Barbosa, A. S., \& Rodrigues, M. G. F. (2019). Influence of the methodology on the formation of zeolite membranes MCM-22 for the oil/water emulsion separation. Ceramica, 65(376), 531-540. https://doi.org/10.1590/0366-69132019653762676

Barbosa, A. S., Barbosa, A. S. \& Rodrigues, M. G. F. (2015). Synthesis of zeolite membrane (MCM-22/ $\alpha$-alumina) and its application in the process of oilwater separation. Desalination and Water Treatment, 56, 3665. https://doi.org/10.1080/19443994.2014.995719

Barbosa, T. L. A. (2019). Síntese das membranas zeolíticas (NaA e SAPO-34 suportadas em alfa-Alumina) e membranas MOF (ZIF-8/alfa-Alumina) visando aplicação preditiva na síntese do metanol via hidrogenação do $\mathrm{CO}_{2}$. 2019. Tese (Doutorado em Engenharia Química), Universidade Federal de Campina Grande, Paraíba.

Barbosa, T. L. A., Silva, F. M. N., Barbosa, A. S., Lima, E. G., Rodrigues, M. G. F. (2020). Synthesis and application of a composite NaA zeolite/gammaalumina membrane for oil-water separation process ( Síntese e aplicação de uma membrana compósita zeólita NaA/gama-alumina para o processo de separação de óleo/água ). Cerâmica, 66, 137-144. http://dx.doi.org/10.1590/0366-69132020663782820

Bullen, J. C.; Saleesongsom, S.; Gallagher, K.; Weiss, D. (2021). A Revised Pseudo-Second-Order Kinetic Model for Adsorption, Sensitive to Changes in Adsorbate and Adsorbent Concentrations. Langmuir, 37, 3189-3201. https://doi.org/10.1021/acs.langmuir.1c00142

Chen, B., Bai, F., Zhu, Y., Xia, Y. (2014). A cost-effective method for the synthesis of zeolitic imidazolate framework-8 materials from stoichiometric precursors via aqueous ammonia modulation at room temperature. Microporous and Mesoporous Materials, 193, 7-14. https://doi.org/10.1016/j.micromeso.2014.03.006

Drioli, E., \& Romano, M., (2001). Progress and new perspectives on integrated membrane operations for sustainable industrial growth. Industrial \& Engineering Chemistry Research, 40, 1277-1300. https://doi.org/10.1021/ie0006209

Ezzati, R. (2020). Derivation of Pseudo-First-Order, Pseudo-Second-Order and Modified Pseudo-First-Order rate equations from Langmuir and Freundlich isotherms for adsorption. Chemical Engineering Journal, 392, 123705. https://doi.org/10.1016/j.cej.2019.123705

Ho Y. S., \& Mckay G. (1999). Pseudo-second order model for sorption processes. Process Biochemistry, 34, 451-465. https://doi.org/10.1016/S00329592(98)00112-5

Ho, Y. S., \& McKay, G. (1998). Kinetic models for the sorption of dye from aqueous solution by wood. Transactions of the Institution of Chemical Engineers, 76, 183-91. http://doi.org/10.1205/095758298529326

Ho, Y. S., \& McKay, G. (1999). Batch lead (II) removal from aqueous solution by peat: equilibrium and kinetics. Process Safety and Environmental Protection. 77, 165-73. http://doi.org/10.1205/095758299529983

Ismail, N. H., Salleh, W. N. W., Ismail, A. F., Hasbullah, H., Yusof, N., Aziz, F., \& Jaafar, J. (2020). Hydrophilic polymer-based membrane for oily wastewater treatment: A review. Separation and Purification Technology, 233, 116007. https://doi.org/10.1016/j.seppur.2019.116007

Li, D., Zhao, Y., Wang, X., Tang, W. N., Wu, F., Yu, D., \& Elfalleh, W. (2020). Effects of (+)-catechin on a rice bran protein oil-in-water emulsion: Droplet size, zeta-potential, emulsifying properties, and rheological behavior. Food Hydrocolloids, 98, 105306.

Lin, K. A., Chen, Y., \& Phattarapattama, S. (2016). Efficient demulsification of oil in water emulsions using a zeolitic imidazolate framework: Adsorptive removal of oil droplets from water. Journal of Colloid and Interface Science, 478, 97-106.

Melgar, V. M. A., Kim, J., \& Othman, M. R. (2015). Zeolitic imidazolate framework membranes for gas separation: A review of synthesis methods and gas separation performance. Journal of Industrial and Engineering Chemistry, 28, 1-15. https://doi.org/10.1016/j.jiec.2015.03.006

Mota, M. F., Rodrigues, M. G. F., Machado, F. (2014). Oil-Water Separation Process with Organoclays: A Comparative Analysis. Applied Clay Science, 99, 237-245. http://dx.doi.org/10.1016/j.clay.2014.06.039

Obaid, M., Barakat, N. A., Fadali, O. A., Motlak, M., Almajid, A. A., \& Khalil, K. A., (2015). Effective and reusable oil/water separation membranes based on modified polysulfone electrospun nanofiber mats. Chemical engineering Journal, 259, 449-456. https://doi.org/10.1016/j.cej.2014.07.095 
Payra, S., Challagulla, S., Chakraborty, C., \& Roy, S. A. (2019). Hydrogen evolution reaction induced unprecedentedly rapid electrocatalytic reduction of 4nitrophenol over ZIF-67 compare to ZIF-8. Journal of Electroanalytical Chemistry, 853, 113545. https://doi.org/10.1016/j.jelechem.2019.113545

Phan, A., Doonan, C. J., Uribe-Romo, F. J., Knobler, C. B., O’keeffe, M., \& Yaghi, O. M. (2010). Synthesis, structure and carbon dioxide capture properties of zeolitic imidazolate frameworks. Accounts of Chemical Research, 43, 58-67. https://doi.org/10.1021/ar900116g

Pintor, A. M. A., Vilar, V. J. P., Botelho, C. M. S., \& Boaventura, R. A. R. (2016). Oil and grease removal from wastewaters: Sorption treatment as an alternative to state-of-the-art technologies. A critical review. Chemical Enginering Journal, 297, 229-255. https://doi.org/10.1016/j.cej.2016.03.121

Rashed, M. N. (2013). Adsorption Technique for the Removal of Organic Pollutants from Water and Wastewater. Organic Pollutants - Monitor, Risk and Treatment.

Rodrigues, D. P. A. (2021). Síntese de estruturas metalorgânicas zeolitic imidazolate framework-8: influência da cristalinidade e aplicação no processo de separação emulsão óleo/água. Dissertação (Mestrado em Engenharia Química), Universidade Federal de Campina Grande, Paraíba.

Rodrigues, D. P. A., Barbosa, T. L. A., \& Rodrigues, M. G. F. (2020). Zeolitic Imidazolate Framework-8 Nanoparticles for Rhodamine B Adsorption. Current Nanomaterials, 6, 1- 8. https://doi.org/10.2174/2468187310999201120091142

Rodrigues, D. P. A., Barbosa, T. L. A., \& Rodrigues, M. G. F. (2020). Adsorção de Rodamina B em ZIF-8 e ZIF-67: Efeito nas estruturas. In Engenharia no Século XXI (pp. 16 - 29). http//doi/10.36229/978-65-86127-45-4.CAP.03

Rodrigues, M. G. F., Barbosa, T. L. A., \& Rodrigues, D. P. A. (2020). Zinc imidazolate framework-8 nanoparticle application in oil removal from oil/water emulsion and reuse. Journal of Nanoparticles Research, 22, 328-342. https://doi.org/10.1007/s11051-020-05036-w

Rodrigues, M. G. F., Rodrigues, D. P. A., \& Barbosa, T. L. A., (2019). Preparação da estrutura metalorgânica ZIF-8 e sua aplicação na separação emulsão óleo/água: utilização e reutilização. In XXI Congreso Argentino de Catálisis e X Congreso de Catálisis del Mercosur.

Rodrigues, M. G. F., Tomaz, P. F., Rodrigues, D. P. A., \& Barbosa, T. L. A., (2019). Síntese, caracterização e aplicação de ZIF no processo de separação emulsão Óleo/Água. In XXI Congreso Argentino de Catálisis e X Congreso de Catálisis del Mercosur.

Sann, E. E., Pan, Y., Gao, Z., Zhan, S., Xia, F. (2018). Highly hydrophobic ZIF-8 particles and application for oil-water separation. Separation and Purification Technology, 206,186-191. https://doi.org/10.1016/j.seppur.2018.04.027

Shams, M., Dehghani, M. H., Nabizadeh, R., Mesdaghinia, A., Alimohammadi, M., Najafpoor, A. A. (2016). Adsorption of phosphorus from aqueous solution by cubic zeolitic imidazolate framework-8: Modeling, mechanical agitation versus sonication. Journal of Molecular Liquids, 224, 151-157. https://doi.org/10.1016/j.molliq.2016.09.059

Scheibler, J. R., Santos, E. R. F., Barbosa, A. S., \& Rodrigues, M. G. F. (2014). Performance of zeolite membrane (ZSM-5/ $\gamma$-Alumina) in the oil/water separation process. Desalination and Water Treatment, 56(13), 3561-3567. https://doi.org/10.1080/19443994.2014.986536

Tian, Q., Liu, Q., Zhou, J., Ju, P., Waterhouse, Gin, Zhou, S., \& Ai, S. (2019). Superhydrophobic sponge containing silicone oil-modified layered double hydroxide sheets for rapid oil-water separations. Colloids and Surfaces A: Physicochemical and Engineering Aspects, 570, 339-346. https://doi.org/10.1016/j.colsurfa.2019.03.031

Tien, C. (1994). Adsorption Calculation and modeling. Boston: Butteworth-Heinemann.

Tomaz, P. F. (2020). Síntese da estrutura metalorgânica ZIF-ZNI para aplicação no tratamento de efluentes oleosos. Dissertação (Mestrado em Química), Universidade Estadual da Paraíba, Paraíba.

Tomaz, P. F., Rodrigues, D. P. A., Barbosa, T. L. A., \& Rodrigues, M. G. F. (2021). Zeolitic Imidazolate Framework ZIF-zni nanocrystals used for Oil-water Separation. Current Nanomaterials, 6, 1- 9. https://doi.org/10.2174/2405461506666210420131237

Wahi, R., Chuah, L. A., Choong, T. S. Y., Ngaini, Z., \& Nourouzi, M. (2013). Oil removal from aqueous state by natural fibrous sorbent: An overview. Separation and Purification Technology, 113, 51-63. https://doi.org/10.1016/j.seppur.2013.04.015

Zhan, B., Liu, Y., Li, S., Kaya, C, Stegmaier, T., Aliabadi, M., Han, Z., \& Ren, L. (2019). Fabrication of superwetting Cu/Cu²O cubic film for oil/water emulsion separation and photocatalytic degradation. Applied Surface Science, 496, 143580. https://doi.org/10.1016/j.apsusc.2019.143580

Zhu, Y., Wang, D., Jiang, L., \& Jin, J., (2014). Recent progress in developing advanced membranes for emulsified oil/water separation. NPG Asia Materials 6, e101. https://doi.org/10.1038/am.2014.23 